\title{
Role of Resveratrol as Radiosensitizer by Targeting Cancer Stem Cells in Radioresistant Prostate Cancer Cells (PC-3)
}

\author{
Sanaa A El-Benhawy ${ }^{1}$, Mohmed I Morsi' ${ }^{1}$, Enayat I Fahmy ${ }^{1}$, Moustafa A Soula ${ }^{2}$, \\ Fatma Al Zahraa FH Khalil ${ }^{3}$, Amal R R Arab ${ }^{4 *}$
}

\begin{abstract}
Aim of Work: Here, we examined the role of resveratrol as a radiosensitizer by targeting cancer stem cells in radioresistant prostate cancer cells (PC-3) using stem cell markers CD44, CD49b and CD29, SOX2, OCT4, CXCR4, DCLK1 and EMT markers such as VIM and E-cadherin. Material and Methods: This study was an in vitro study involving PC-3 cell line which was dividing into four groups. Group I (CO): Control group composed of cells grown in the same medium without treatment with ionizing radiation or resveratrol. Group II (IR): Cells were treated with ionizing radiation alone. Group III (RV): Cells were treated with resveratrol alone. Group VI (IR\&RV): The cells were treated with ionizing radiation and resveratrol in combination. The viability of cells was assessed by MTT assay. Genes of interest were measured by RT-PCR and the radiosensitizing efficacy of RV on proliferating cancer cells was determined by clonogenic assay. Results: Ionizing radiation significantly reduced PC-3 viability, lowered stem cell markers and affected epithelial to mesenchymal transition (EMT) genes expression at all doses (2, 4, 6 and 8 Gray). Resveratrol significantly decreased PC-3 viability and lowered stem cell markers and EMT genes expression at concentrations 35, 70 and $140 \mu \mathrm{M}$. Combining resveratrol treatment with ionizing radiation leads to significant reduction in cell viability and stem cell markers genes which was noticed with increasing the radiation dose when compared to ionizing radiation alone treated group. Conclusion: Resveratrol has a radiosensitizing effect, that ability is triggered by reducing the expression of cancer stem cell markers and affecting EMT markers. Resveratrol showed to be a good candidate for further studies as anticancer drug in the treatment of human prostate cancer.
\end{abstract}

Keywords: Prostate cancer- Ionizing radiation- PC-3- Resveratrol-Stem cell markers- EMT

Asian Pac J Cancer Prev, 22 (12), 3823-3837

\section{Introduction}

The most common cancer in men is Prostate cancer (PC) which is the fifth leading cause for cancer-related deaths (Rawla, 2019). Very commonly, radiotherapy, chemotherapy or radical prostatectomy with or without androgen deprivation therapy are used. (Shipley et al., 2017). A standard prostate cancer cell line is known to be the PC-3 cell. It has been used as a prototype for androgen independent prostate cancer. In contrast, this cell line has a higher metastatic potential, in comparison to different prostate cancer cell line patterns (Kamalidehghan et al., 2018). Radio-resistance of prostate cancer cells has a range of features, including raise in the number of epithelial mesenchymal transition, neuroendocrine differentiation and cancer stem cells (Murata et al., 2019). For reduction in the radiation exposure and side effects linked with radiation therapy for prostate cancer, a safe and efficient radiosensitizer drug is required. Radiosensitizers are agents that sensitize the cancer cells to radiation. (Gong et al., 2021). Recent research has shown that treatment with resveratrol can sensitize tumor cells to ionizing radiation and chemotherapy agents (Mortezaee et al., 2020). Resveratrol is a natural polyphenol (trans-3, 4, 5-trihydroxystilbene) compound (Sun et al., 2019) found in over 70 plant forms, including hellebore, giant knotweed, grapes, and peanuts (Koushki et al., 2018).

Cancer stem cells (CSCs) have been known as cancer cells that are qualified of self-renewal and trigger the heterogeneous cancer cell lineages that form the cancer cells. (Fulawka et al., 2014). This capability to survive suggests that Cancer stem cells could drive post-treatment recurrence and cancer progression, and targeting these CSCs would increase the efficiency of cancer treatment, leading to an increasing number of patients being cured (Harris and Kerr, 2017). Several biomarkers such as CD44, CD49b, CD29, SOX2, OCT4 and CXCR4 have

${ }^{1}$ Department of Radiation Sciences, Medical Research Institute, Alexandria University, Alexandria, Egypt. ${ }^{2}$ Department of Radiology, October Central Hospital, El Gharbeya, Egypt. ${ }^{3}$ Department of Radiology, College of Applied Medical Sciences, Misr University for Science and technology, Giza, Egypt. ${ }^{4}$ Department of Applied Medical Chemistry, Medical Research Institute, Alexandria University, Alexandria,Egypt.*For Correspondence: amal_rifaat@yahoo.com 
been used to classify CSCs in prostate cancer (Kobayashi and Noronha, 2015).

\section{Materials and Methods}

\section{Study Design}

The present study is an in vitro study employing prostate cancer cell (PC-3) which was cultured into four groups: Group I (CO): Control group composed of cells grown without treatment with ionizing radiation or resveratrol. Group II (IR): Cells treated with ionizing radiation alone (exposed to various doses 2, 4, 6 and $8 \mathrm{~Gy}$ ). Group III (RV): Cells treated with different concentrations of resveratrol alone $(140,70$ and $35 \mu \mathrm{M})$. Group IV (IR\&RV): Cells treated with different concentrations of resveratrol $(140,70$ and $35 \mu \mathrm{M})$ plus ionizing radiation at different doses (2, 4, 6 and 8) Gray (Gy).

\section{Cell Culture}

Prostate cancer cell (PC-3) was purchased from National Cancer Institute, Egypt. Cells were cultivated with ten percent $(\mathrm{v} / \mathrm{v})$ fetal bovine serum (FBS) (SigmaAldrich, MO, USA), replenished in Dulbecco's Modified Eagle's Medium (DMEM) (Lonza, Verviers, Belgium). In a humidified $37^{\circ} \mathrm{C}$ incubator, cell culture was maintained in 5\% CO2 atmosphere. Cells were developed until 70-80 percent confluence was achieved at that time, they were subjected to the planned experimental treatment regimens.

\section{MTT assay}

Cells were plated in triplicate with an inoculum of $10^{4}$ cells/well for PC-3 at day zero in 96-well microtiter plate. At $37^{\circ} \mathrm{C}$ in $5 \% \mathrm{CO}_{2}$ overnight, the microtiter plate was then incubated. The different treatments were added on day one according to the calculated doses except on control well. The plate was then incubated at the same condition for 72 hours. $100 \mu \mathrm{l}$ of membrane filtered MTT reagent (SERVA Electrophoresis GmbH - Heidelberg Germany) at a last concentration of $5 \mathrm{mg} / \mathrm{ml}$ were append per well. The plate in the same state had been incubated for 2 hours until purple precipitate was apparent. The supernatant was extracted neatly. $100 \mu 1$ (per well) of Dimethyl sulfoxide were append for solubilizing formazan crystals and the microtiter plate was put on the shaker for 3 minutes to ensure homogeneity of the color. A microplate reader set to $490 \mathrm{~nm}$ was used to define the optical density of each well. Cell viability was calculated according to the following formula:

$\%$ Cell viability $=($ mean Abs of treated cells $) /($ mean Abs of untreated cells $) \times 100$

\section{Clonogenic assay}

Cells were implanted in 6-well microtiter plate and treated with resveratrol $(35 \mu \mathrm{M})$ and ionizing radiation at different doses (2, 4, 6 and 8 Gy). Cultural media was exchanged twenty-four hours after irradiation with new complete drug removal media and accompanied by incubation at $37^{\circ} \mathrm{C}$ for $8-12$ days to permit forming colony. Remove the medium above the cells then lotion cells with phosphate buffered saline. Fix cells with methanol: acetic acid (3:1) then incubates for 5 minutes. Remove the fixing reagent and stained cells with 0.5 percent crystal violet in methanol for thirty minutes. Wash by tap water. Let the colony plates dry at room temperature. Using colony counter pen and a stereomicroscope to count the colonies and measure the survival rate. Plating efficiency (PE) is the ratio between the numbers of seeded cells to number of colonies:

$$
\mathrm{PE}=\frac{\text { no.of colonies formed }}{\text { no.of cells seeded }} \chi 100 \%
$$

The surviving fraction (SF) is defined as the number of colonies that occur after cell therapy, expressed in terms of plating efficiency:

$$
\mathrm{SF}=\frac{\text { no. of colonies formed after treatment }}{\text { no. of cells seeded } \times \mathrm{PE}}
$$

\section{Irradiation procedure}

At room temperature, cells were irradiated in 96-well microtiter plate. The cell culture plates were irradiated horizontally in upright position at a dose rate of $300 \mathrm{MU} /$ minute for the time needed to apply different doses $(2,4$, 6 , and $8 \mathrm{~Gy}$ ). The field of the radiation range was $18 \times 13$ $\mathrm{cm}, \mathrm{SSD}=97.7 \mathrm{~cm}$ from the target. The linear accelerator (Elekta), generating $6 \mathrm{MV}$ photon X-ray in Ayady Almostakbal Hospital, Alexandria, Egypt. Cells were always spot in the middle of the field. After irradiation, cells were collected, and pellets were stored at $-80^{\circ} \mathrm{C}$ for determination of gene expression by RT-PCR.

\section{Real-time PCR}

Total RNA was extracted from PC-3 cells using a highly denaturating guanidine-thiocyanate containing buffer, which immediately inactivates RNases to ensure purification of intact RNA (RNeasy Mini Kit, Qiagen, Hilden, Germany). Total RNA reverse-transcription and amplification reactions taking place sequentially in the same tube in $25 \mu$ f final volume of reaction mix using one step Rotor Gene SYBR Green PCR Kit (Qiagen, Hilden, Germany) according to the manufacturer's protocol. All primers used in this study were predesigned (QuantiTect Primer Assay, Qiagen, Germany). Glyceraldehyde-3phosphate dehydrogenase (GAPDH) was used as internal control to normalize the expression of genes of interest. The relative expression level of each transcript was calculated by the $2^{-\Delta \Delta \mathrm{Ct}}$ method.

\section{Statistical analysis of the data}

The data was transmitted to the computer and analyzed using IBM SPSS software version 20.0 (Armonk, NY: IBM Corp). The Kolmogorov-Smirnov test was used to check the normality of distribution. Quantitative data were described using mean and standard error of triplicate data. F-test (ANOVA) was used for normally distributed quantitative variables, to compare between more than two groups, and Post Hoc test (Tukey) for pairwise comparisons. Significance of the obtained results was judged at the $5 \%$ level. 


\section{Results}

Cytotoxic effect of ionizing radiation, resveratrol and combination treatment of both ionizing radiation and resveratrol on viability of $P C-3$

The results showed that, the mean \pm SD of PC-3 cell viability was $94.30 \pm 3.60$ at $2 \mathrm{~Gy}, 93.42 \pm 3.64$ at $4 \mathrm{~Gy}$, $85.71 \pm 9.75$ at 6 Gy and $75.96 \pm 1.65$ at 8 Gy, PC-3 cells viability was significantly reduced in a dose-dependent manner when treated with ionizing radiation especially at dose 6 Gray and 8 Gray while insignificantly decreased at dose 2 Gray and 4 Gray when compared to untreated group. Regarding Resveratrol treatment, the mean $\pm \mathrm{SD}$ of PC-3 cell viability was $37.71 \pm 6.30$ at IC50 (140 $\mu \mathrm{M}), 73.47 \pm 7.25$ at $70 \mu \mathrm{M}$ and $77.41 \pm 8.80$ at 35 $\mu \mathrm{M}$, cell viability was significantly decreased in a dosedependent manner with resveratrol at concentration 35 $\mu \mathrm{M}, 70 \mu \mathrm{M}$, and $140 \mu \mathrm{M}$ when compared to untreated group. Combining resveratrol treatment at different concentrations with ionizing radiation leads to significant depression in cell viability when compared to radiation only treated group. (Table 1, Figure 1).
Radiosensitizing Effect of Resveratrol on PC-3 Cells

Effect of ionizing radiation, Resveratrol and combination treatment of both ionizing radiation and resveratrol on CD44, CD49b and CD29 genes expression in PC-3 cell line.

Statistical analysis of data showed that, CD44 gene expression was significantly decreased following treatment of PC-3 cells with ionizing radiation at all doses when compared to the untreated control group. Expression of CD44 gene was significantly decreased following treatment of cells with resveratrol at different concentrations when compared to untreated control group. Combining resveratrol treatment at $140,70,35 \mu \mathrm{M}$ with ionizing radiation leads to significant reduction in CD44 gene expression when compared to radiation only treated group (Table 2, Figure $2 \mathrm{a}$ ) (data of 70 and $35 \mu \mathrm{M} \mathrm{RV+IR}$ not shown).

$C D 49 b$ and $C D 29$ genes expression were significantly decreased following treatment of PC-3 cells with ionizing radiation at all doses when compared to the untreated control group. Expression of $C D 49 b$ and $C D 29$ genes were significantly decreased following treatment of PC-3 cells with resveratrol when compared to untreated control group. Combining resveratrol treatment at different concentrations especially, at IC50 $(140 \mu \mathrm{M})$ with ionizing radiation leads to significant reduction in $C D 49 b$ and $C D 29$ genes expression in comparison to ionizing radiation only treated group (Table 2 , Figure $2 \mathrm{~b}$ and $\mathrm{c}$ ) (data of 70 and $35 \mu \mathrm{M}$ RV+IR not shown).

Table 1. Cytotoxic Impact of IR, RV and Combination Treatment of Both IR and RV on PC-3 cells viability by MTT Assay

\begin{tabular}{|c|c|c|c|c|c|}
\hline Cell viability $(\%)$ & Untreated control group & & & & \\
\hline & & & Ionizing radiat & on dose (Gy) & \\
\hline & & 2 Gy & $4 \mathrm{~Gy}$ & $6 \mathrm{~Gy}$ & 8 Gy \\
\hline Mean \pm SD & $100 \pm 0.0$ & $94.30 \pm 3.60$ & $93.42 \pm 3.64$ & $85.71 \pm 9.75$ & $75.96 \pm 1.65$ \\
\hline \multirow[t]{3}{*}{$\mathrm{P}$} & & 0.62 & 0.105 & $0.019 *$ & $<0.001^{*}$ \\
\hline & & \multicolumn{4}{|c|}{ Resveratrol $(\mu \mathrm{M})$} \\
\hline & & $140 \mu \mathrm{M}$ & $70 \mu \mathrm{M}$ & & $35 \mu \mathrm{M}$ \\
\hline Mean \pm SD & $100 \pm 0.0$ & $37.71 \pm 6.30$ & $73.47 \pm 7.25$ & & $77.41 \pm 8.80$ \\
\hline \multirow[t]{3}{*}{$\mathrm{P}$} & & $<0.001^{*}$ & $<0.001^{*}$ & & $<0.001 *$ \\
\hline & & \multicolumn{4}{|c|}{ Radiation dose $(\mathrm{Gy})+$ resveratrol $(140 \mu \mathrm{M})$} \\
\hline & & $2 \mathrm{~Gy}+140 \mu \mathrm{M}$ & $4 \mathrm{~Gy}+140 \mu \mathrm{M}$ & $6 \mathrm{~Gy}+140 \mu \mathrm{M}$ & $8 \mathrm{~Gy}+140 \mu \mathrm{M}$ \\
\hline Mean \pm SD & $100 \pm 0.0$ & $34.80 \pm 12.37$ & $30.26 \pm 2.14$ & $22.68 \pm 6.21$ & $22.24 \pm 2.73$ \\
\hline $\mathrm{P}$ & & $<0.001 *$ & $<0.001^{*}$ & $<0.001^{*}$ & $<0.001^{*}$ \\
\hline \multirow[t]{3}{*}{$\mathrm{P} 1$} & & $<0.001^{*}$ & $<0.001^{*}$ & $<0.001^{*}$ & $<0.001^{*}$ \\
\hline & & \multicolumn{4}{|c|}{ Radiation dose $(\mathrm{Gy})+$ resveratrol $(70 \mu \mathrm{M})$} \\
\hline & & $2 \mathrm{~Gy}+70 \mu \mathrm{M}$ & $4 \mathrm{~Gy}+70 \mu \mathrm{M}$ & $6 \mathrm{~Gy}+70 \mu \mathrm{M}$ & $8 \mathrm{~Gy}+70 \mu \mathrm{M}$ \\
\hline Mean \pm SD & $100 \pm 0.0$ & $83.01 \pm 5.54$ & $67.51 \pm 2.24$ & $65.24 \pm 11.92$ & $53.02 \pm 6.82$ \\
\hline $\mathrm{P}$ & & $0.002 *$ & $<0.001 *$ & $<0.001^{*}$ & $<0.001^{*}$ \\
\hline \multirow[t]{3}{*}{ P1 } & & $0.049 *$ & $<0.001^{*}$ & $0.039 *$ & $<0.001^{*}$ \\
\hline & & \multicolumn{4}{|c|}{ Radiation dose $(\mathrm{Gy})+$ resveratrol $(35 \mu \mathrm{M})$} \\
\hline & & $2 \mathrm{~Gy}+35 \mu \mathrm{M}$ & $4 \mathrm{~Gy}+35 \mu \mathrm{M}$ & $6 \mathrm{~Gy}+35 \mu \mathrm{M}$ & $8 \mathrm{~Gy}+35 \mu \mathrm{M}$ \\
\hline Mean \pm SD & $100 \pm 0.0$ & $89.63 \pm 3.71$ & $68.76 \pm 5.47$ & $66.13 \pm 9.21$ & $65.35 \pm 2.81$ \\
\hline $\mathrm{P}$ & & $0.018^{*}$ & $<0.001^{*}$ & $<0.001 *$ & $<0.001^{*}$ \\
\hline P1 & & 0.72 & $<0.001^{*}$ & $<0.001^{*}$ & 0.082 \\
\hline
\end{tabular}

* Statistically significant at $\mathrm{p} \leq 0.05 ; \mathrm{P}, \mathrm{p}$ value for comparing between untreated control group and the other group; P1, $\mathrm{p}$-value for comparing between radiation only treated group and radiation + Resveratrol-treated group. 


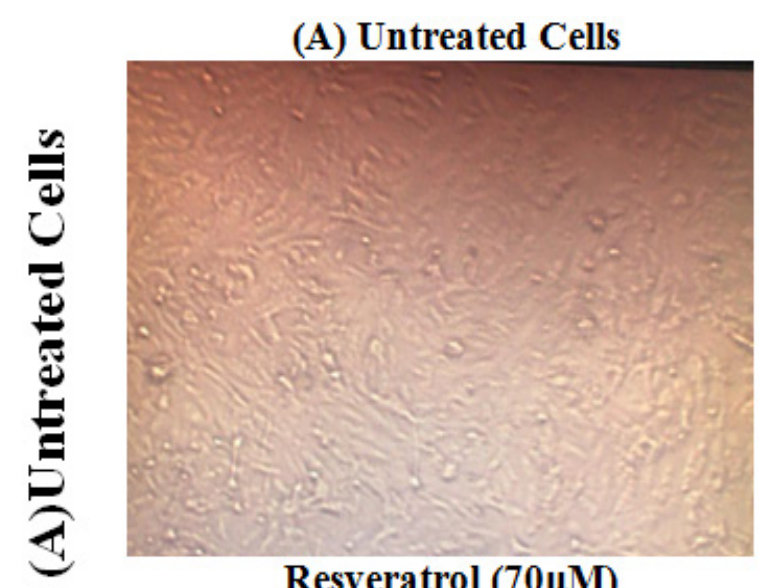

Resveratrol $(70 \mu \mathrm{M})$

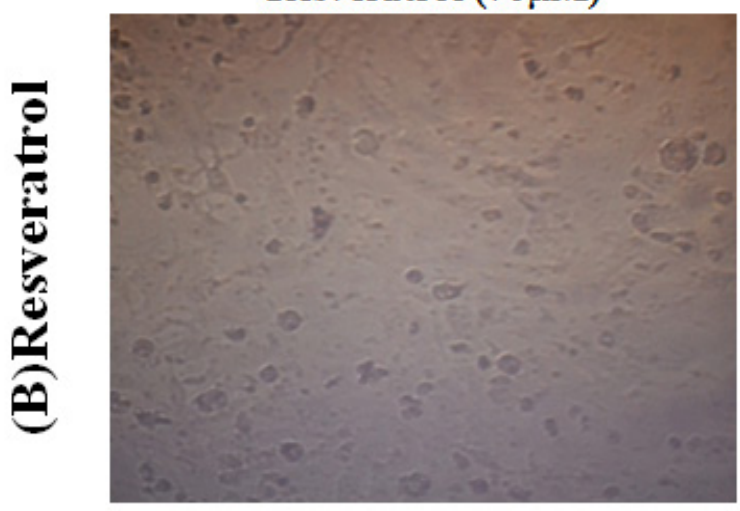

(C) 2 Gy
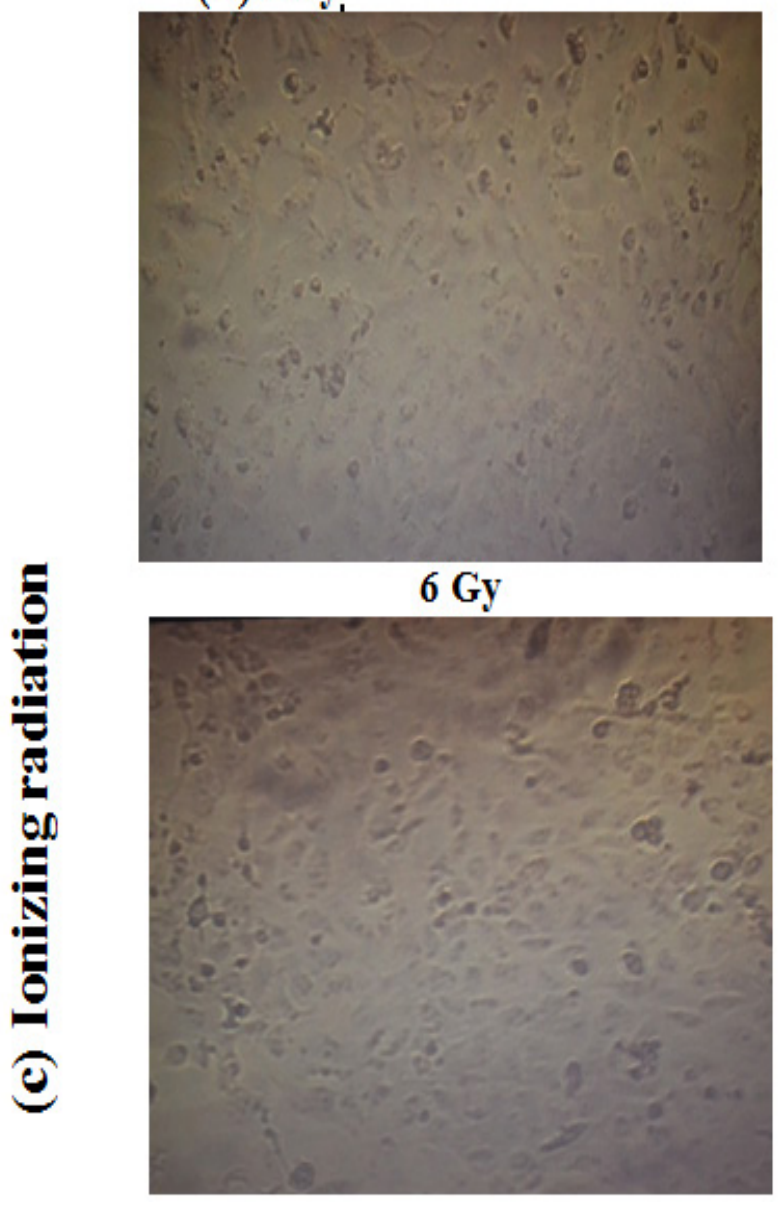

(B) Resveratrol $(35 \mu \mathrm{M})$

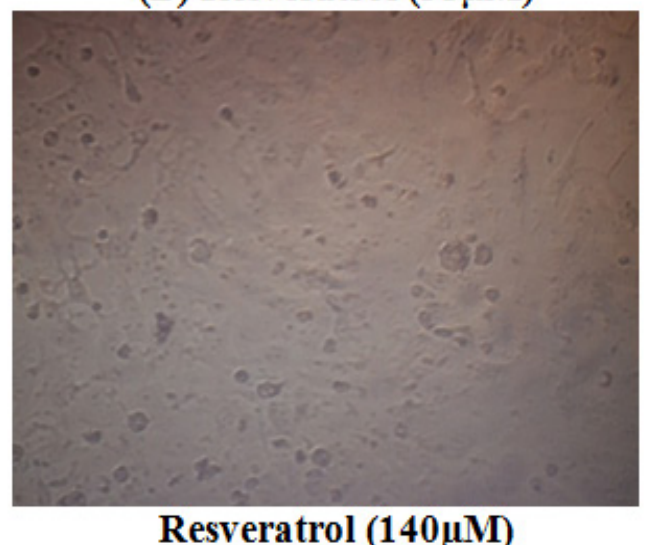

Resveratrol $(140 \mu \mathrm{M})$

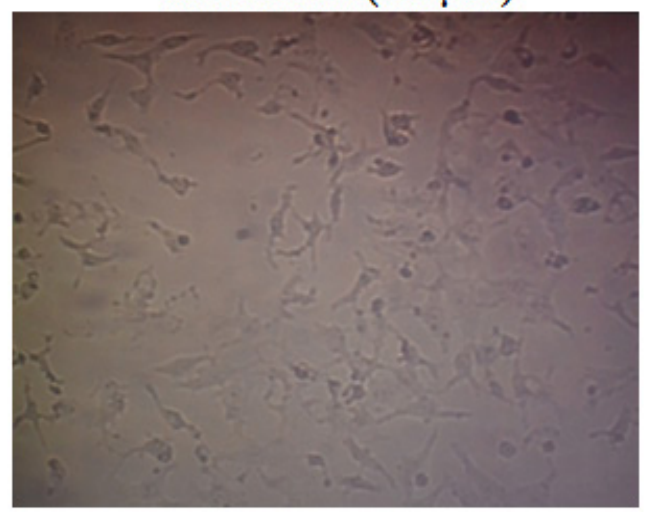

$4 \mathrm{~Gy}$

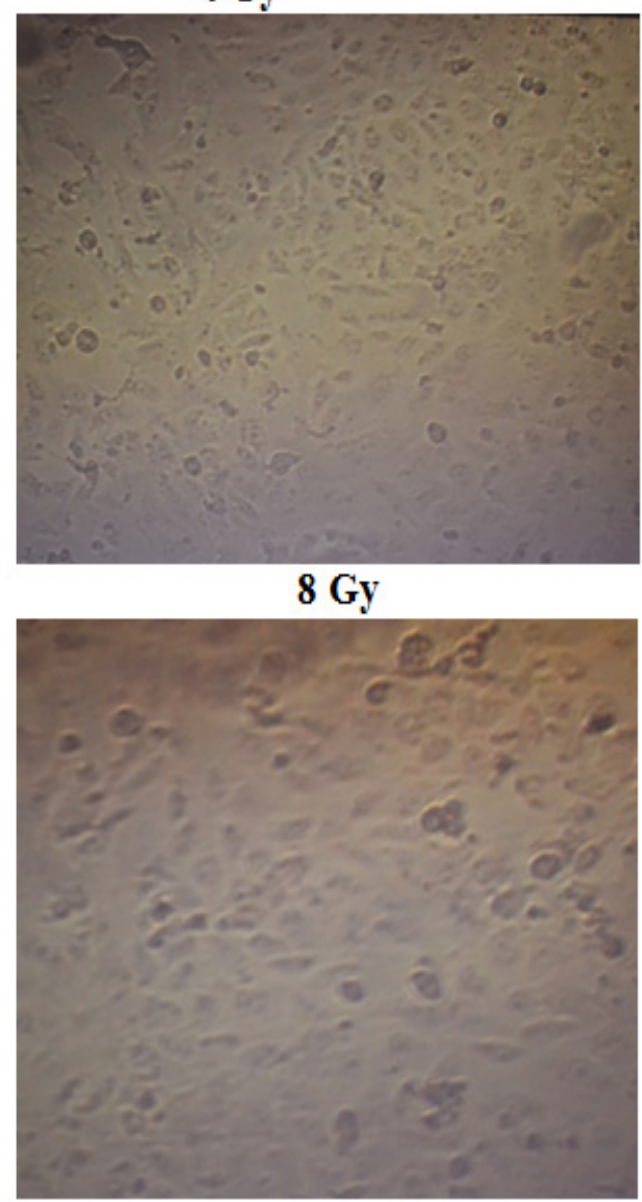




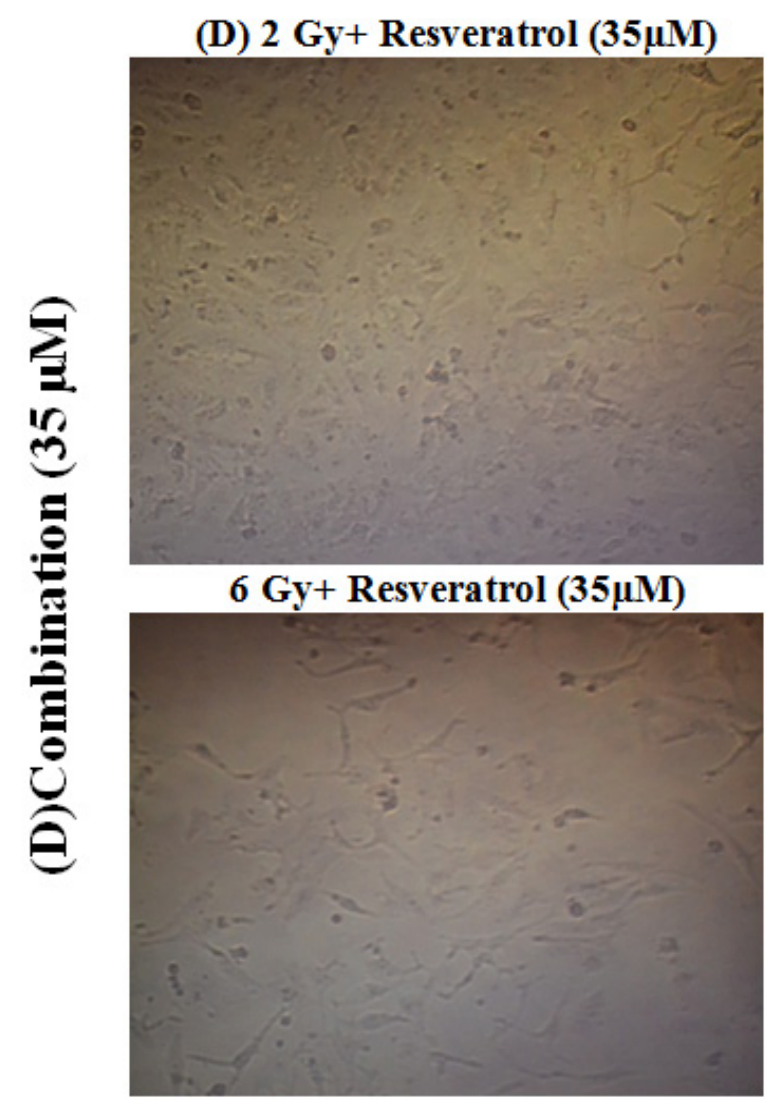

4 Gy+ Resveratrol (35 $\mu M)$

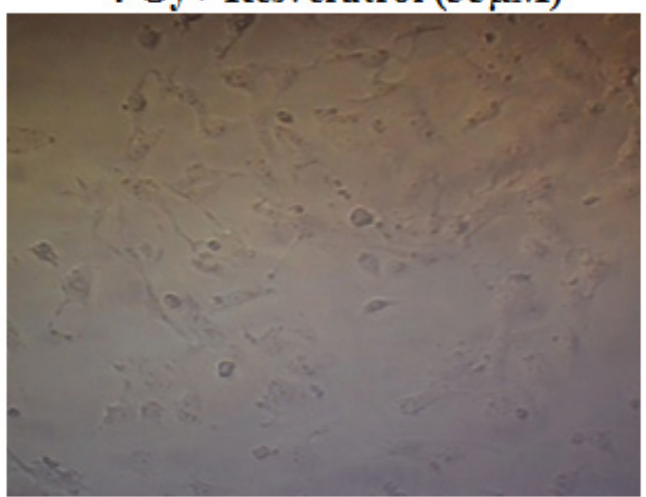

8 Gy+ Resveratrol $(35 \mu \mathrm{M})$

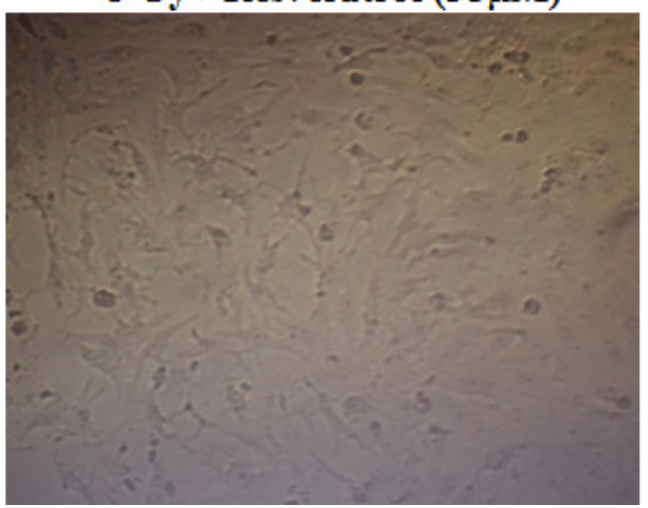

(E) $2 \mathrm{~Gy}+$ Resveratrol $(70 \mu \mathrm{M})$

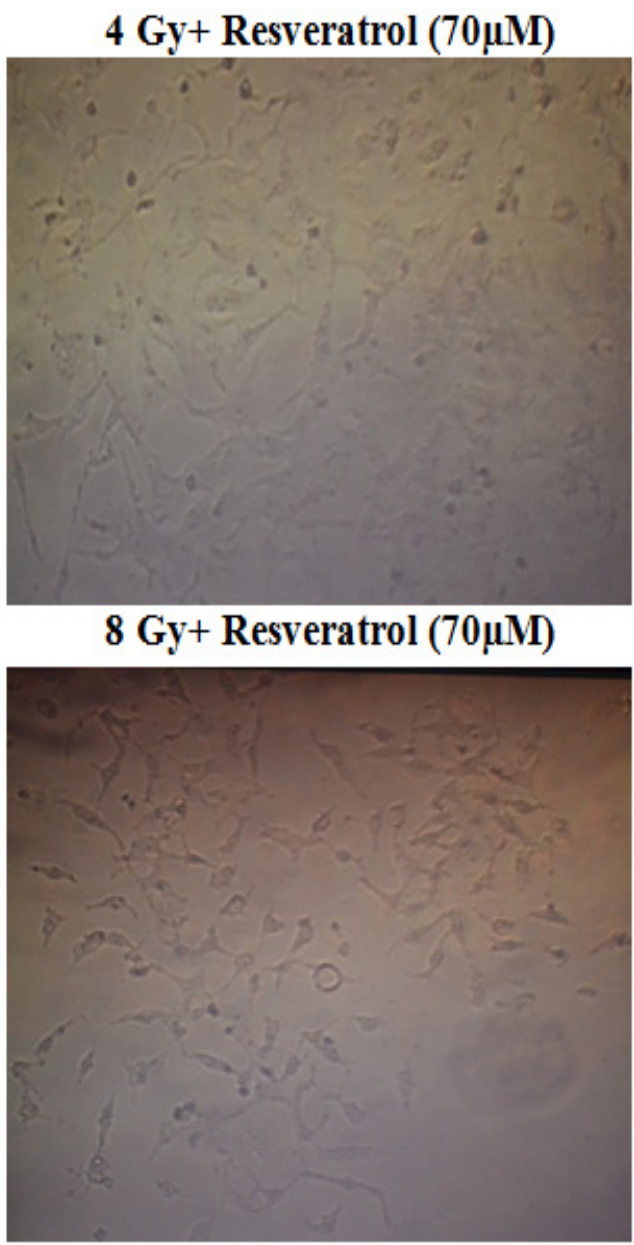



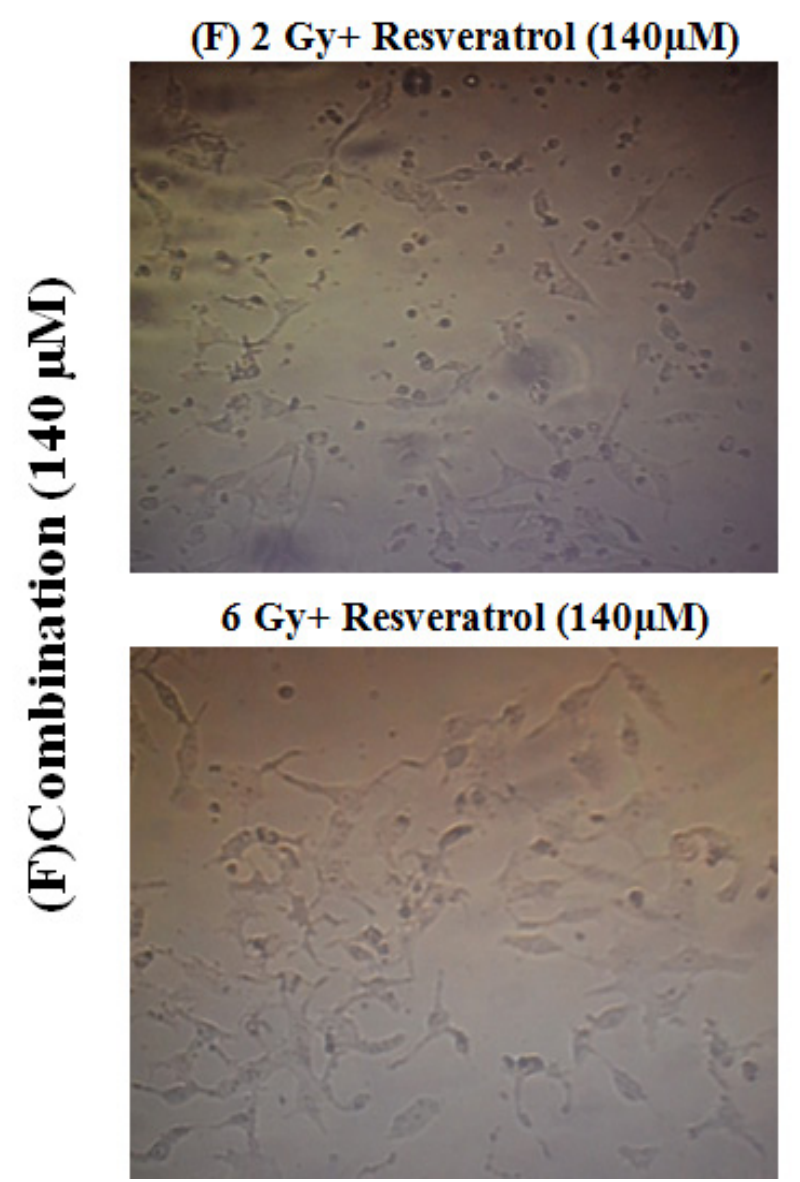

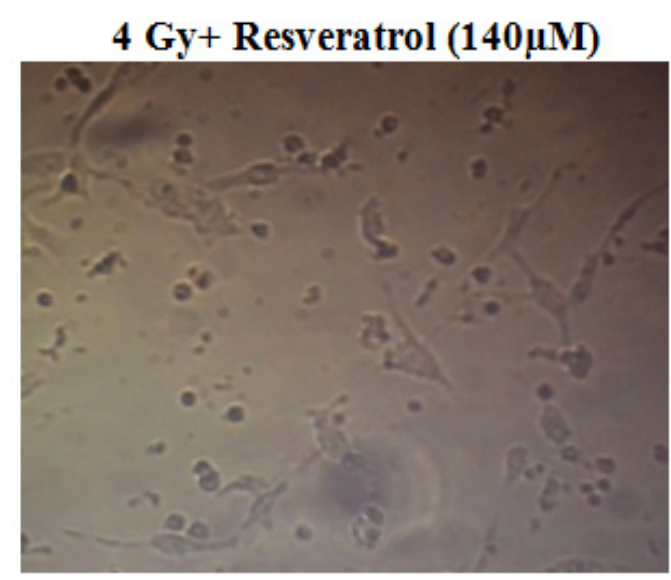

$8 \mathrm{~Gy}+$ Resveratrol $(\mathbf{1 4 0 \mu M )}$

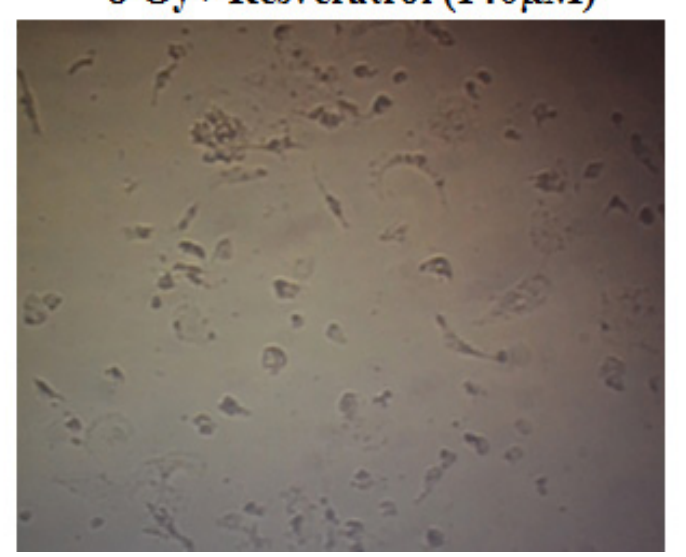

Figure 1. Morphological Alterations of PC-3Cell Line Observed by Inverted Microscopy. (A) untreated control (B) Resveratrol at different concentrations $(140,70$ and $35 \mu \mathrm{M})$ group; (C) Ionizing radiation at different doses $(2,4$, 6 and $8 \mathrm{~Gy}$ ); (D) Combination of ionizing radiation and resveratrol at $35 \mu \mathrm{M}$; (E) Combination of ionizing radiation and resveratrol at $70 \mu \mathrm{M} ;(\mathrm{F})$ Combination of ionizing radiation and resveratrol at $140 \mu \mathrm{M}$.

Effect of ionizing radiation, Resveratrol and combination treatment of both ionizing radiation and Resveratrol on SOX2, OCT4 and DCLK1 genes expression in PC-3 cell line

Statistical analysis of data showed that SOX2, OCT4 and $D C L K 1$ genes expression were significantly decreased following treatment of $\mathrm{PC}-3$ cells with ionizing radiation at all doses when compared to the untreated control group except DCLK1 at dose 2 Gy. Expression of these genes were significantly decreased when PC-3 cells were treated with resveratrol in comparison to untreated cells. Combining resveratrol treatment at different concentrations especially, at $\mathrm{IC}_{50}(140 \mu \mathrm{M})$ with ionizing radiation leads to significant reduction in SOX2, OCT4 and DCLK1 genes expression in comparison to ionizing radiation only treated group. (Table 3 and Figures $3 a, b$ and c) (data of 70 and $35 \mu \mathrm{M} R \mathrm{R}+\mathrm{IR}$ not shown).

Effect of ionizing radiation, Resveratrol and combination treatment of both ionizing radiation and Resveratrol on CXCR4, VIM and E-cadherin genes expression in PC-3 cell line.

Statistical analysis of data showed that CXCR4 expression was significantly increased after exposure to ionizing radiation at all doses when compared to the untreated control group. Expression of this gene was significantly decreased when PC-3 cells were treated with resveratrol alone at $\mathrm{IC}_{50}(140 \mu \mathrm{M})$. Combining resveratrol treatment at different concentrations especially, at 140 $\mu \mathrm{M}$ with ionizing radiation leads to significant reduction in expression of this gene when compared to ionizing radiation only treated group. VIM gene expression was significantly decreased following treatment of PC-3 cells with ionizing radiation at all doses when compared to the untreated control group. Expression of this gene was significantly decreased when PC-3 cells were treated with resveratrol in comparison to untreated cells. Combining resveratrol treatment at different concentrations especially, at $\mathrm{IC}_{50}(140 \mu \mathrm{M})$ with ionizing radiation leads to significant reduction in expression of VIM gene when compared to ionizing radiation only treated group.

Expression of E-cadherin gene was insignificantly increased when PC-3 cells were exposed to ionizing radiation at all doses

Expression of E-cadherin gene was significantly increased when PC-3 cells were treated with resveratrol in comparison to untreated cells, especially, at 140 and $70 \mu \mathrm{M}$. Combining resveratrol treatment at different concentrations especially, at IC50 $(140 \mu \mathrm{M})$ with ionizing radiation leads to significant increase in E-cadherin gene expression in comparison to ionizing radiation only treated 
Table 2. Impact of IR, RV and Combination Treatment of Both IR and RV on Expression of CD44, CD49b and CD29 Genes

\begin{tabular}{|c|c|c|c|c|c|}
\hline Fold change & Untreated group & & & & \\
\hline & & \multicolumn{4}{|c|}{ Ionizing radiation dose (Gy) } \\
\hline CD44 & & 2 Gy & 4 Gy & 6 Gy & 8 Gy \\
\hline Mean \pm SE & $1 \pm 0.0$ & $0.71 \pm 0.06$ & $0.57 \pm 0.05$ & $0.31 \pm 0.025$ & $0.17 \pm 0.01$ \\
\hline \multirow[t]{3}{*}{$\mathrm{P}$} & & $0.019 *$ & $<0.001 *$ & $<0.001^{*}$ & $<0.001 *$ \\
\hline & & \multicolumn{4}{|c|}{ Resveratrol $(\mu \mathrm{M})$} \\
\hline & & $140 \mu \mathrm{M}$ & $70 \mu \mathrm{M}$ & $35 \mu \mathrm{M}$ & \\
\hline Mean \pm SE & $1 \pm 0.0$ & $0.13 \pm 0.011$ & $0.37 \pm 0.021$ & $0.39 \pm 0.026$ & \\
\hline \multirow[t]{3}{*}{$\mathrm{P}$} & & $<0.001 *$ & $<0.001^{*}$ & $<0.001 *$ & \\
\hline & & \multicolumn{4}{|c|}{ Radiation dose $(\mathrm{Gy})+$ resveratrol $(140 \mu \mathrm{M})$} \\
\hline & & $2 \mathrm{~Gy}+140 \mu \mathrm{M}$ & $4 \mathrm{~Gy}+140 \mu \mathrm{M}$ & $6 \mathrm{~Gy}+140 \mu \mathrm{M}$ & $8 \mathrm{~Gy}+140 \mu \mathrm{M}$ \\
\hline Mean \pm SE & $1 \pm 0.0$ & $0.29 \pm 0.031$ & $0.25 \pm 0.022$ & $0.12 \pm 0.005$ & $0.06 \pm 0.001$ \\
\hline $\mathrm{P}$ & & $<0.001 *$ & $<0.001 *$ & $<0.001 *$ & $<0.001 *$ \\
\hline P1 & & $0.004 *$ & $0.019 *$ & $<0.001^{*}$ & $<0.001 *$ \\
\hline \multicolumn{6}{|l|}{$\mathrm{CD} 49 \mathrm{~b}$} \\
\hline & & \multicolumn{4}{|c|}{ Ionizing radiation dose (Gy) } \\
\hline & & 2 Gy & 4 Gy & 6 Gy & 8 Gy \\
\hline Mean \pm SE & $1 \pm 0.0$ & $0.70 \pm 0.054$ & $0.46 \pm 0.041$ & $0.34 \pm 0.018$ & $0.22 \pm 0.013$ \\
\hline \multirow[t]{3}{*}{$\mathrm{P}$} & & $0.013^{*}$ & $<0.001 *$ & $<0.001^{*}$ & $<0.001^{*}$ \\
\hline & & \multicolumn{4}{|c|}{ Resveratrol $(\mu \mathrm{M})$} \\
\hline & & $140 \mu \mathrm{M}$ & $70 \mu \mathrm{M}$ & $35 \mu \mathrm{M}$ & \\
\hline Mean \pm SE & $1 \pm 0.0$ & $0.18 \pm 0.009$ & $0.22 \pm 0.015$ & $0.63 \pm 0.034$ & \\
\hline \multirow[t]{3}{*}{$\mathrm{P}$} & & $<0.001 *$ & $<0.001 *$ & $0.002 *$ & \\
\hline & & \multicolumn{4}{|c|}{ Radiation dose $(\mathrm{Gy})+$ resveratrol $(140 \mu \mathrm{M})$} \\
\hline & & $2 \mathrm{~Gy}+140 \mu \mathrm{M}$ & $4 \mathrm{~Gy}+140 \mu \mathrm{M}$ & $6 \mathrm{~Gy}+140 \mu \mathrm{M}$ & $8 \mathrm{~Gy}+140 \mu \mathrm{M}$ \\
\hline Mean \pm SE & $1 \pm 0.0$ & $0.30 \pm 0.026$ & $0.28 \pm 0.017$ & $0.20 \pm 0.010$ & $0.10 \pm 0.003$ \\
\hline $\mathrm{P}$ & & $<0.001 *$ & $<0.001 *$ & $<0.001^{*}$ & $<0.001 *$ \\
\hline P1 & & $0.005^{*}$ & $0.037^{*}$ & 0.431 & 0.239 \\
\hline \multirow[t]{2}{*}{$\mathrm{CD} 29$} & & \multicolumn{4}{|c|}{ Ionizing radiation dose (Gy) } \\
\hline & & 2 Gy & $4 \mathrm{~Gy}$ & 6 Gy & 8 Gy \\
\hline Mean \pm SE & $1 \pm 0.0$ & $0.89 \pm 0.075$ & $0.63 \pm 0.049$ & $0.30 \pm 0.026$ & $0.20 \pm 0.016$ \\
\hline \multirow[t]{3}{*}{$\mathrm{P}$} & & 0.583 & $0.004^{*}$ & $<0.001^{*}$ & $<0.001^{*}$ \\
\hline & & Resveratrol $(\mu \mathrm{M})$ & & & \\
\hline & & $140 \mu \mathrm{M}$ & $70 \mu \mathrm{M}$ & $35 \mu \mathrm{M}$ & \\
\hline Mean \pm SE & $1 \pm 0.0$ & $0.0123 \pm 0.001$ & $0.0796 \pm 0.006$ & $0.310 \pm 0.0214$ & \\
\hline \multirow[t]{3}{*}{$\mathrm{P}$} & & $<0.001 *$ & $<0.001 *$ & $<0.001 *$ & \\
\hline & & \multicolumn{4}{|c|}{ Radiation dose $(\mathrm{Gy})+$ resveratrol $(140 \mu \mathrm{M})$} \\
\hline & & $2 \mathrm{~Gy}+140 \mu \mathrm{M}$ & $4 \mathrm{~Gy}+140 \mu \mathrm{M}$ & $6 \mathrm{~Gy}+140 \mu \mathrm{M}$ & $8 \mathrm{~Gy}+140 \mu \mathrm{M}$ \\
\hline Mean \pm SE & $1 \pm 0.0$ & $0.35 \pm 0.044$ & $0.25 \pm 0.015$ & $0.11 \pm 0.003$ & $0.07 \pm 0.001$ \\
\hline $\mathrm{P}$ & & $<0.001 *$ & $<0.001 *$ & $<0.001 *$ & $<0.001 *$ \\
\hline P1 & & $0.001 *$ & $0.008^{*}$ & $0.036^{*}$ & $0.021 *$ \\
\hline
\end{tabular}

* Statistically significant at $\mathrm{p} \leq 0.05 ; \mathrm{P}, \mathrm{p}$ value for comparing between untreated control group and the other group; $\mathrm{P} 1, \mathrm{p}$-value for comparing between radiation only treated group and radiation + Resveratrol treated group.

group. (Table 4 and Figures $4 \mathrm{a}, \mathrm{b}$ and c) (data of 70 and $35 \mu \mathrm{M}$ RV+IR not shown).

Radio-sensitizing effect of Resveratrol $(35 \mu M)$ on PC-3 cell line

Surviving fraction was significantly decreased in a dose dependent manner following treatment of PC-3 cells with IR at all doses. Mean \pm SE of surviving fraction was $0.6968 \pm 4.35$ at 2 Gy, $0.4892 \pm 3.57$ at 4 Gy, $0.3193 \pm 2.80$ at $6 \mathrm{~Gy}$ and $0.1711 \pm 2.59$ at $8 \mathrm{~Gy}$. Combining resveratrol treatment at $35 \mu \mathrm{M}$ with IR leads to significant depression in surviving fraction which was noticed with increasing the radiation dose. Mean \pm SE of surviving fraction after combination treatment at $35 \mu \mathrm{M}$ Resveratrol was 0.5249 

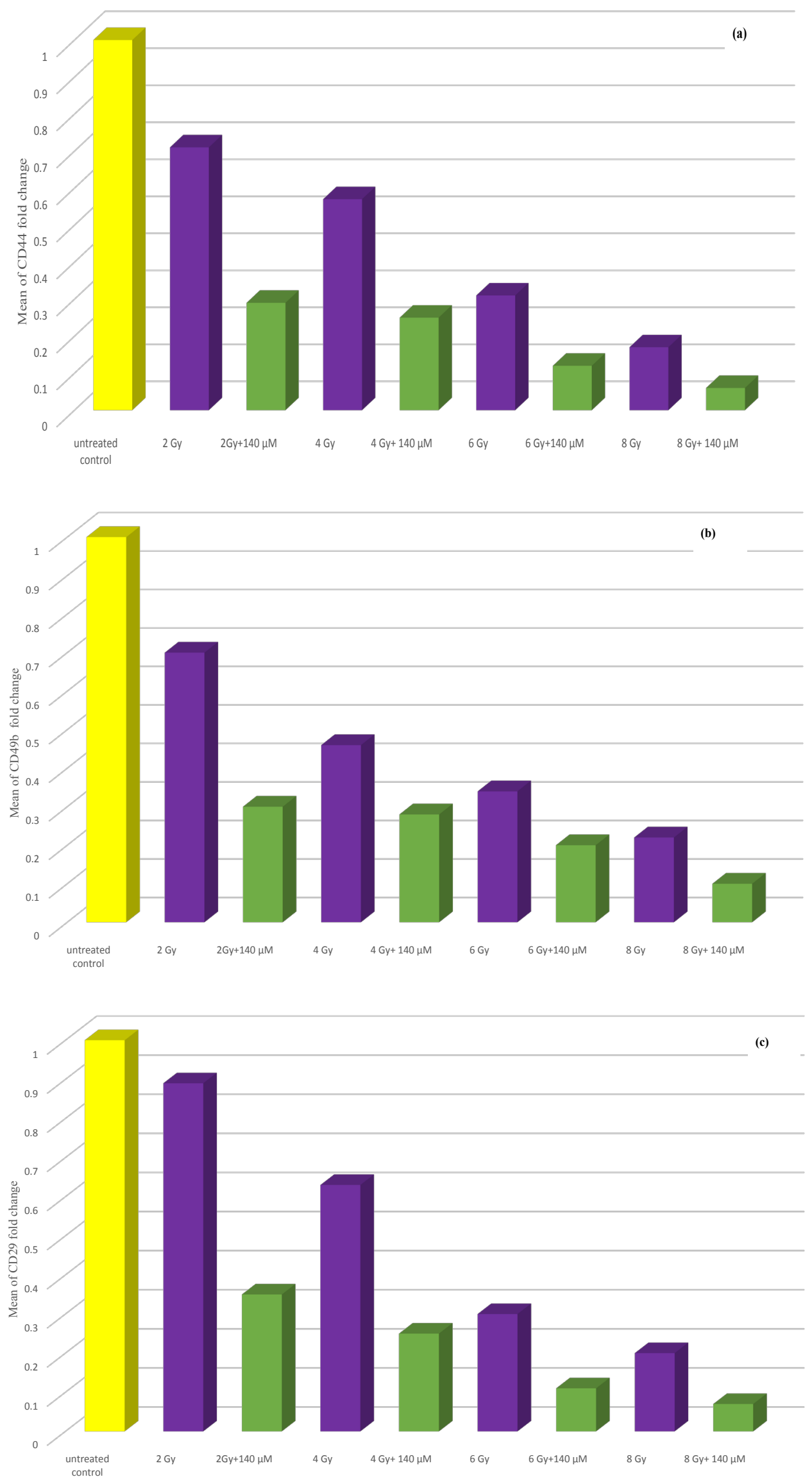

Figure 2. (a) Bar chart illustrating the effect of combination treatment of both ionizing radiation and resveratrol at $\mathrm{IC}_{50}$ $(140 \mu \mathrm{M})$ on CD44 gene expression in PC-3 cell line. (b) Bar chart illustrating the effect of combination treatment of both ionizing radiation and resveratrol at $\mathrm{IC}_{50}(140 \mu \mathrm{M})$ on $C D 49 b$ gene expression in PC-3 cell line. (c) Bar chart illustrating the effect of combination treatment of both ionizing radiation and resveratrol at $\operatorname{IC}_{50}(140 \mu \mathrm{M})$ on $C D 29$ gene expression in PC-3 cell line. 
Table 3. Impact of IR, RV and Combination Treatment of Both IR and RV on Expression of SOX2, OCT4 and DCLK1 Genes

\begin{tabular}{|c|c|c|c|c|c|}
\hline Fold change & Untreated group & & & & \\
\hline \multirow[t]{2}{*}{ SOX2 } & \multicolumn{5}{|c|}{ Ionizing radiation dose $(\mathrm{Gy})$} \\
\hline & & 2 Gy & 4 Gy & 6 Gy & 8 Gy \\
\hline Mean \pm SE & $1 \pm 0.0$ & $1.03 \pm 0.09$ & $0.84 \pm 0.03$ & $0.63 \pm 0.03$ & $0.32 \pm 0.06$ \\
\hline \multirow[t]{3}{*}{$\mathrm{P}$} & & 0.996 & 0.288 & $0.008 *$ & $0.003 *$ \\
\hline & & \multicolumn{4}{|c|}{ Resveratrol $(\mu \mathrm{M})$} \\
\hline & & $140 \mu \mathrm{M}$ & $70 \mu \mathrm{M}$ & & $35 \mu \mathrm{M}$ \\
\hline Mean \pm SE & $1 \pm 0.0$ & $0.67 \pm 0.07$ & $0.70 \pm 0.08$ & & $0.89 \pm 0.11$ \\
\hline \multirow[t]{3}{*}{$\mathrm{P}$} & & $<0.001 *$ & $<0.001 *$ & & 0.715 \\
\hline & & \multicolumn{4}{|c|}{ Radiation dose $(\mathrm{Gy})+$ resveratrol $(140 \mu \mathrm{M})$} \\
\hline & & $2 \mathrm{~Gy}+140 \mu \mathrm{M}$ & $4 \mathrm{~Gy}+140 \mu \mathrm{M}$ & $6 \mathrm{~Gy}+140 \mu \mathrm{M}$ & $8 \mathrm{~Gy}+140 \mu \mathrm{M}$ \\
\hline Mean \pm SE & $1 \pm 0.0$ & $0.55 \pm 0.02$ & $0.44 \pm 0.03$ & $0.25 \pm 0.02$ & $0.02 \pm 0.0$ \\
\hline $\mathrm{P}$ & & $<0.001^{*}$ & $<0.001^{*}$ & $<0.001^{*}$ & $<0.001^{*}$ \\
\hline P1 & & $<0.001^{*}$ & $<0.001^{*}$ & $<0.001^{*}$ & $<0.001 *$ \\
\hline \multirow[t]{2}{*}{ OCT4 } & & \multicolumn{4}{|c|}{ Ionizing radiation dose $(\mathrm{Gy})$} \\
\hline & & 2 Gy & 4 Gy & 6 Gy & 8 Gy \\
\hline Mean \pm SE & $1 \pm 0.0$ & $3.36 \pm 0.13$ & $1.57 \pm 0.06$ & $1.29 \pm 0.05$ & $0.79 \pm 0.03$ \\
\hline \multirow[t]{3}{*}{$\mathrm{P}$} & & $<0.001 *$ & $<0.001^{*}$ & 0.082 & 0.264 \\
\hline & & \multicolumn{4}{|l|}{ Resveratrol $(\mu \mathrm{M})$} \\
\hline & & $140 \mu \mathrm{M}$ & & $70 \mu \mathrm{M}$ & $35 \mu \mathrm{M}$ \\
\hline Mean \pm SE & $1 \pm 0.0$ & $0.14 \pm 0.03$ & & $0.30 \pm 0.10$ & $0.62 \pm 0.09$ \\
\hline \multirow[t]{3}{*}{$\mathrm{P}$} & & $<0.001 *$ & & $<0.001^{*}$ & $0.021^{*}$ \\
\hline & & \multicolumn{4}{|c|}{ Radiation dose $(\mathrm{Gy})+$ resveratrol $(140 \mu \mathrm{M})$} \\
\hline & & $2 \mathrm{~Gy}+140 \mu \mathrm{M}$ & $4 \mathrm{~Gy}+140 \mu \mathrm{M}$ & $6 \mathrm{~Gy}+140 \mu \mathrm{M}$ & $8 \mathrm{~Gy}+140 \mu \mathrm{M}$ \\
\hline Mean \pm SE & $1 \pm 0.0$ & $0.12 \pm 0.04$ & $0.08 \pm 0.02$ & $0.02 \pm 0.001$ & $0.02 \pm 0.001$ \\
\hline $\mathrm{P}$ & & $<0.001 *$ & $<0.001 *$ & $<0.001^{*}$ & $<0.001^{*}$ \\
\hline $\mathrm{P} 1$ & & $<0.001^{*}$ & $<0.001^{*}$ & $<0.001^{*}$ & $<0.001^{*}$ \\
\hline \multirow[t]{2}{*}{ DCLK1 } & & \multicolumn{4}{|c|}{ Ionizing radiation dose (Gy) } \\
\hline & & 2 Gy & 4 Gy & $6 \mathrm{~Gy}$ & 8 Gy \\
\hline Mean \pm SE & $1 \pm 0.0$ & $1.36 \pm 0.09$ & $0.94 \pm 0.03$ & $0.63 \pm 0.03$ & $0.58 \pm 0.02$ \\
\hline \multirow[t]{3}{*}{$\mathrm{P}$} & & $<0.001 *$ & 0.872 & $0.018^{*}$ & $<0.001^{*}$ \\
\hline & & \multicolumn{4}{|c|}{ Resveratrol $(\mu \mathrm{M})$} \\
\hline & & $140 \mu \mathrm{M}$ & & $70 \mu \mathrm{M}$ & $35 \mu \mathrm{M}$ \\
\hline \multirow[t]{4}{*}{ Mean \pm SE } & $1 \pm 0.0$ & $0.26 \pm 0.07$ & & $0.36 \pm 0.07$ & $0.75 \pm 0.07$ \\
\hline & & $<0.001^{*}$ & & $<0.001^{*}$ & $0.048^{*}$ \\
\hline & & \multicolumn{4}{|c|}{ Radiation dose $(\mathrm{Gy})+$ resveratrol $(140 \mu \mathrm{M})$} \\
\hline & & $2 \mathrm{~Gy}+140 \mu \mathrm{M}$ & $4 \mathrm{~Gy}+140 \mu \mathrm{M}$ & $6 \mathrm{~Gy}+140 \mu \mathrm{M}$ & $8 \mathrm{~Gy}+140 \mu \mathrm{M}$ \\
\hline Mean \pm SE & $1 \pm 0.0$ & $0.19 \pm 0.01$ & $0.15 \pm 0.02$ & $0.008 \pm 0.003$ & $0.005 \pm 0.001$ \\
\hline$P$ & & $<0.001 *$ & $<0.001^{*}$ & $<0.001^{*}$ & $<0.001^{*}$ \\
\hline $\mathrm{P} 1$ & & $<0.001 *$ & $<0.001^{*}$ & $<0.001 *$ & $<0.001^{*}$ \\
\hline
\end{tabular}

* Statistically significant at $\mathrm{p} \leq 0.05 ; \mathrm{P}, \mathrm{p}$ value for comparing between untreated control group and the other group; P1, $\mathrm{p}$-value for comparing between radiation only treated group and radiation + Resveratrol treated group.

\pm 3.89 at $2 \mathrm{~Gy}, 0.3219 \pm 4.30$ at $4 \mathrm{~Gy}, 0.2008 \pm 3.20$ at 6 Gy and $0.0488 \pm 1.42$ at 8 Gy (Figure 5).

\section{Discussion}

The most widespread malignancy and main reason of death related to cancer in males is prostate cancer. It is a significant health issue, especially in ageing populations, as it is usually diagnosed in men over the age of 50 years (Jasiński et al., 2013). Current therapies for prostate cancer, consisting of radical prostatectomy, radiotherapy, hormone therapy, and chemotherapy (Huang et al., 2015). In prostate cancer cells, radiotherapy is utilized to damage deoxyribonucleic acid by ionizing radiation to induce programed cell death. A confirmed percentage of patients do not adapt to this treatment and become metastatic due to 

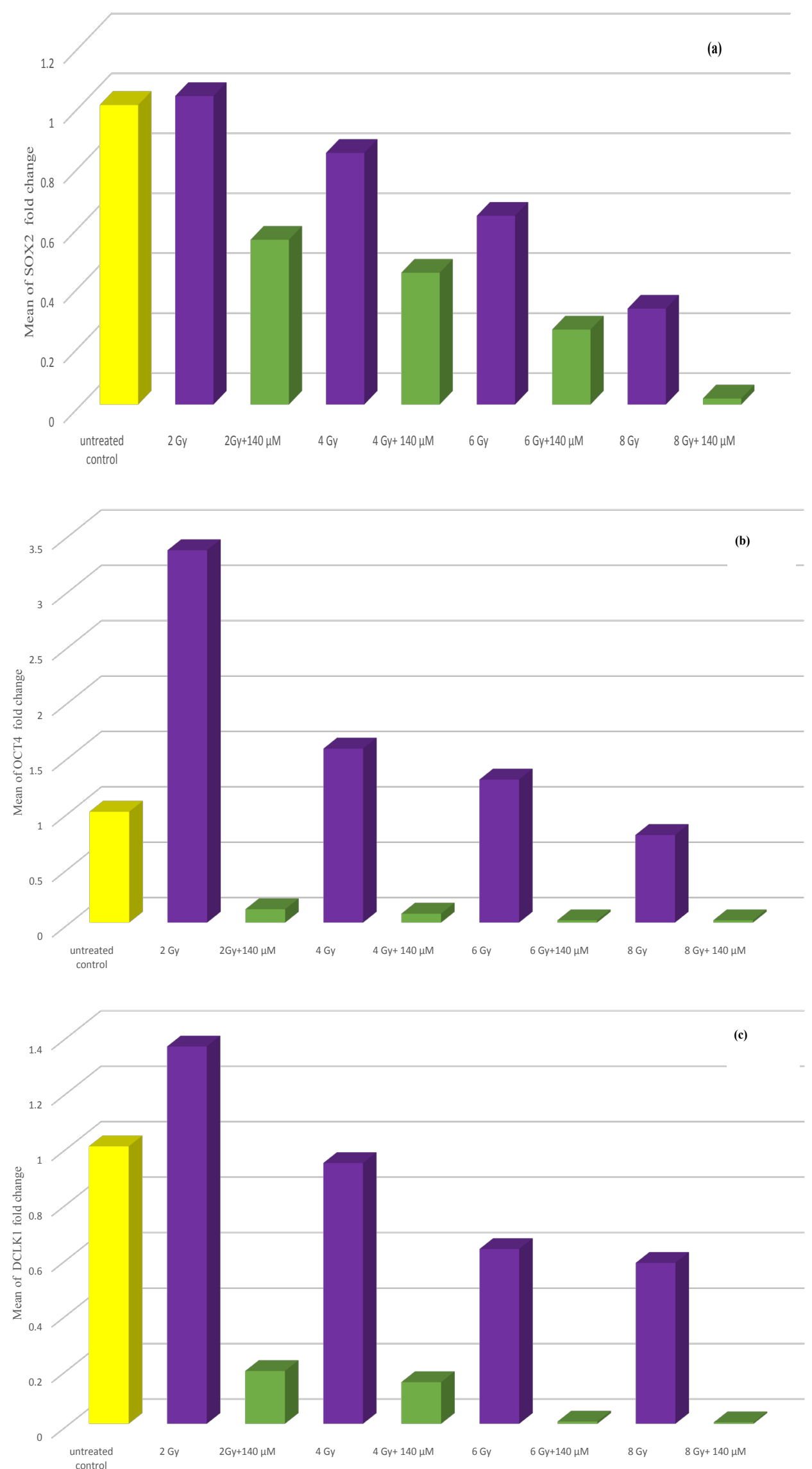

Figure 3. (a) Bar chart illustrating the effect of combination treatment of both ionizing radiation and resveratrol at IC50 $(140 \mu \mathrm{M})$ on SOX2 gene expression in PC-3 cell line. (b) Bar chart illustrating the effect of combination treatment of both ionizing radiation and resveratrol at IC50 $(140 \mu \mathrm{M})$ on OCT4 gene expression in PC-3 cell line. (c) Bar chart illustrating the effect of combination treatment of both ionizing radiation and resveratrol at IC50 (140 $\mu \mathrm{M})$ on DCLK1 gene expression in PC-3 cell line. 
Table 4. Impact of IR, RV and Combination Treatment of Both IR and RV on Expression of CXCR4, VIM and E-cadherin Genes

\begin{tabular}{|c|c|c|c|c|c|}
\hline \multirow[t]{2}{*}{ Fold change } & Untreated group & & & & \\
\hline & \multicolumn{5}{|c|}{ Ionizing radiation dose (Gy) } \\
\hline CXCR4 & & $2 \mathrm{~Gy}$ & 4 Gy & 6 Gy & 8 Gy \\
\hline Mean \pm SE & $1 \pm 0.0$ & $13.64 \pm 0.22$ & $7.14 \pm 0.06$ & $5.17 \pm 0.09$ & $3.77 \pm 0.19$ \\
\hline \multirow[t]{3}{*}{$\mathrm{P}$} & & $<0.001^{*}$ & $<0.001 *$ & $<0.001 *$ & $0.014^{*}$ \\
\hline & & \multicolumn{4}{|c|}{ Resveratrol $(\mu \mathrm{M})$} \\
\hline & & $140 \mu \mathrm{M}$ & $70 \mu \mathrm{M}$ & $35 \mu \mathrm{M}$ & \\
\hline Mean \pm SE & $1 \pm 0.0$ & $0.48 \pm 0.08$ & $2.96 \pm 0.07$ & $6.54 \pm 0.18$ & \\
\hline \multirow[t]{3}{*}{$\mathrm{P}$} & & $0.036^{*}$ & $<0.001 *$ & $<0.001 *$ & \\
\hline & & \multicolumn{4}{|c|}{ Radiation dose $(\mathrm{Gy})+$ resveratrol $(140 \mu \mathrm{M})$} \\
\hline & & $2 \mathrm{~Gy}+140 \mu \mathrm{M}$ & $4 \mathrm{~Gy}+140 \mu \mathrm{M}$ & $6 \mathrm{~Gy}+140 \mu \mathrm{M}$ & $8 \mathrm{~Gy}+140 \mu \mathrm{M}$ \\
\hline Mean \pm SE & $1 \pm 0.0$ & $0.38 \pm 0.02$ & $0.35 \pm 0.03$ & $0.33 \pm 0.04$ & $0.27 \pm 0.03$ \\
\hline $\mathrm{P}$ & & $0.007 *$ & $<0.001 *$ & $<0.001^{*}$ & $0.005^{*}$ \\
\hline P1 & & $<0.001 *$ & $<0.001 *$ & $<0.001 *$ & $<0.001 *$ \\
\hline \multicolumn{6}{|l|}{ VIM } \\
\hline & & \multicolumn{4}{|c|}{ Ionizing radiation dose (Gy) } \\
\hline & & 2 Gy & 4 Gy & 6 Gy & 8 Gy \\
\hline Mean \pm SE & $1 \pm 0.0$ & $0.87 \pm 0.07$ & $0.79 \pm 0.06$ & $0.44 \pm 0.03$ & $0.29 \pm 0.01$ \\
\hline \multirow[t]{3}{*}{$\mathrm{P}$} & & 0.406 & 0.089 & $<0.001 *$ & $<0.001 *$ \\
\hline & & \multicolumn{4}{|l|}{ Resveratrol $(\mu \mathrm{M})$} \\
\hline & & $140 \mu \mathrm{M}$ & $70 \mu \mathrm{M}$ & $35 \mu \mathrm{M}$ & \\
\hline Mean \pm SE & $1 \pm 0.0$ & $0.22 \pm 0.01$ & $0.57 \pm 0.04$ & $0.76 \pm 0.06$ & \\
\hline \multirow[t]{3}{*}{$\mathrm{P}$} & & $<0.001 *$ & $<0.001^{*}$ & $0.036^{*}$ & \\
\hline & & \multicolumn{4}{|c|}{ Radiation dose $(\mathrm{Gy})+$ resveratrol $(140 \mu \mathrm{M})$} \\
\hline & & $2 \mathrm{~Gy}+140 \mu \mathrm{M}$ & $4 \mathrm{~Gy}+140 \mu \mathrm{M}$ & $6 \mathrm{~Gy}+140 \mu \mathrm{M}$ & $8 \mathrm{~Gy}+140 \mu \mathrm{M}$ \\
\hline Mean \pm SE & $1 \pm 0.0$ & $0.48 \pm 0.06$ & $0.32 \pm 0.02$ & $0.13 \pm 0.01$ & $0.01 \pm 0.001$ \\
\hline $\mathrm{P}$ & & $<0.001^{*}$ & $<0.001^{*}$ & $<0.001^{*}$ & $<0.001^{*}$ \\
\hline P1 & & $0.006^{*}$ & $0.002 *$ & $<0.001^{*}$ & $0.006^{*}$ \\
\hline \multirow[t]{2}{*}{ E-cadherin } & & \multicolumn{4}{|c|}{ Ionizing radiation dose $(\mathrm{Gy})$} \\
\hline & & 2 Gy & 4 Gy & 6 Gy & 8 Gy \\
\hline Mean \pm SE & $1 \pm 0.0$ & $1.13 \pm 0.09$ & $1.81 \pm 0.09$ & $2.01 \pm 0.08$ & $2.88 \pm 0.04$ \\
\hline \multirow[t]{3}{*}{$P$} & & 0.787 & 0.648 & 0.510 & 0.190 \\
\hline & & \multicolumn{4}{|c|}{ Resveratrol $(\mu \mathrm{M})$} \\
\hline & & $140 \mu \mathrm{M}$ & $70 \mu \mathrm{M}$ & $35 \mu \mathrm{M}$ & \\
\hline Mean \pm SE & $1 \pm 0.0$ & $3.84 \pm 0.05$ & $3.28 \pm 0.05$ & $2.72 \pm 0.07$ & \\
\hline \multirow[t]{3}{*}{$\mathrm{P}$} & & $0.006^{*}$ & $0.033^{*}$ & 0.147 & \\
\hline & & \multicolumn{4}{|c|}{ Radiation dose $(\mathrm{Gy})+$ resveratrol $(140 \mu \mathrm{M})$} \\
\hline & & $2 \mathrm{~Gy}+140 \mu \mathrm{M}$ & $4 \mathrm{~Gy}+140 \mu \mathrm{M}$ & $6 \mathrm{~Gy}+140 \mu \mathrm{M}$ & $8 \mathrm{~Gy}+140 \mu \mathrm{M}$ \\
\hline Mean \pm SE & $1 \pm 0.0$ & $4.13 \pm 0.06$ & $4.51 \pm 0.07$ & $4.91 \pm 0.05$ & $5.0 \pm 0.06$ \\
\hline $\mathrm{P}$ & & $0.009^{*}$ & $0.005^{*}$ & $0.002 *$ & $0.002 *$ \\
\hline P1 & & $<0.001^{*}$ & $<0.001 *$ & $<0.001 *$ & $<0.001 *$ \\
\hline
\end{tabular}

* Statistically significant at $\mathrm{p} \leq 0.05 ; \mathrm{P}, \mathrm{p}$ value for comparing between untreated control group and the other group; P1, $\mathrm{p}$-value for comparing between radiation only treated group and radiation + Resveratrol treated group.

radioresistance (Chen et al., 2017). Novel researches have shown that the evolution of radioresistance is partially due to inhibition of apoptosis (Wang et al., 2017). Radiation therapy has been confirmed to remove the plurality of non-CSCs. However, few CSCs are known, which show relative radioresistance through reduced ROS production and successful DNA repair (Murata et al., 2019). In general, subpopulations of cancer stem cells are more associated with radioresistance than subpopulations of non- CSCs (Chang et al., 2015). Resveratrol, one of those high-grade polyphenols found in red wine and grapes, has been thoroughly researched for its effects on prostate cancer (Amor et al., 2018).

The results of the present study demonstrate that Asian Pacific Journal of Cancer Prevention, Vol 22 

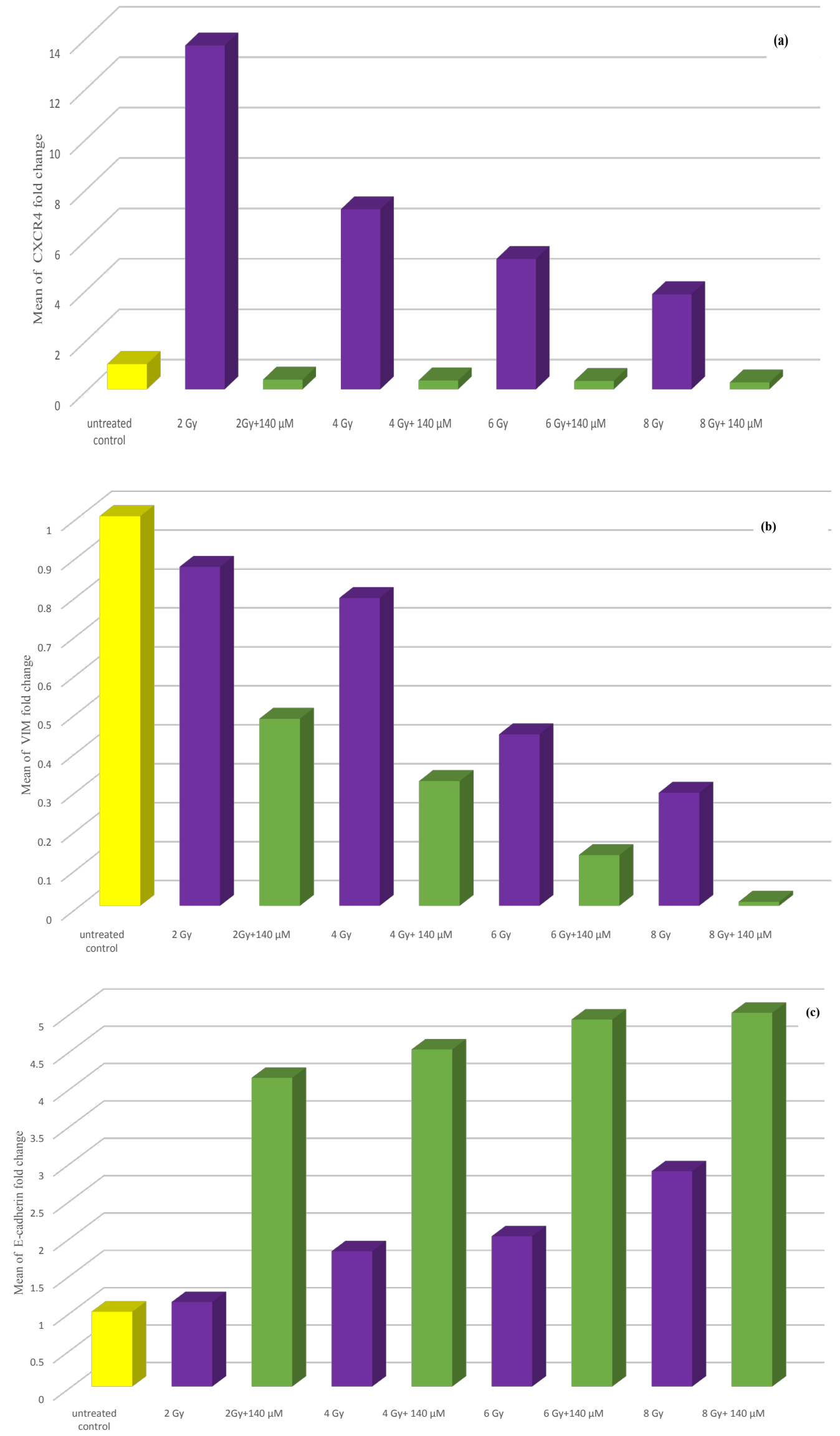

Figure 4. (a) Bar chart illustrating the effect of combination treatment of both ionizing radiation and resveratrol at $\mathrm{IC}_{50}(140 \mu \mathrm{M})$ on CXCR4 gene expression in PC-3 cell line. (b) Bar chart illustrating the effect of combination treatment of both ionizing radiation and resveratrol at $\mathrm{IC}_{50}(140 \mu \mathrm{M})$ on VIM gene expression in PC-3 cell line. (c) Bar chart illustrating the effect of combination treatment of both ionizing radiation and resveratrol at $\mathrm{IC}_{50}(140 \mu \mathrm{M})$ on E-cadherin gene expression in PC-3 cell line. 


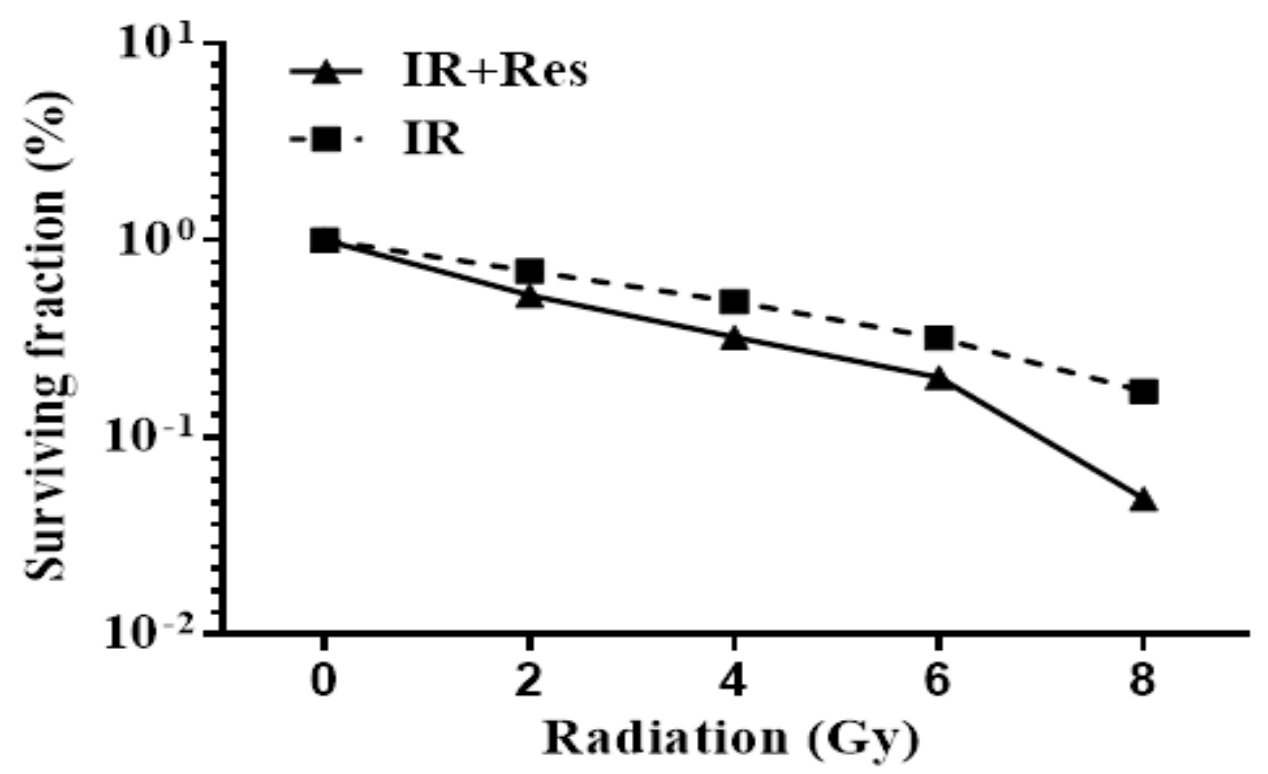

Figure 5. Bar Chart Illustrating Clonogenic Survival Curves for Ionizing Radiation (2, 4, 6 and 8 Gy) alone and Combination Treatment of Both Ionizing Radiation and Resveratrol $(35 \mu \mathrm{M})$ on PC-3 Cell Line.

resveratrol has cytotoxic effect on PC3 cells and enhance the efficacy of IR. Noticeably, the findings of this study showed that combining ionizing radiation with resveratrol produced a synergistic antitumor effect. Previous researches confirmed that $\mathrm{PC}-3$ cells are relatively radioresistant, partly due to apoptosis inhibition. (Diaz et al., 2009; Chen et al., 2018). We and others have shown that resveratrol therapy sensitizes tumor cells to cell death caused by ionizing radiation. (Fang et al., 2013 ; Naponelli et al., 2014). In line with our results, Data from several groups has shown that resveratrol increases radiation sensibility in prostate tumor by preventing cell propagation and facilitating cell senescence and programed cell death (Fang et al., 2013; Chen et al., 2017). Resveratrol anticarcinogenic action has been widely researched in both in vitro and in vivo tumor models including prostate tumor. It is well known that resveratrol stimulate cell cycle arrest in androgen-independent prostate tumor cells, inhibits cell propagation and causes programed cell death (Selvaraj et al., 2016; Silk et al., 2021).

The current research revealed a significant reduction in expression of stem cell markers genes including CD44, CD49b, CD29, SOX2, OCT4, and DCLK1 genes in PC-3 cells after exposure to ionizing radiation at all doses when compared to untreated group except CXCR4 significantly increased. Also resveratrol treatment leads to significant decrease in stem cells markers genes especially at $\mathrm{IC}_{50}(140 \mu \mathrm{M})$. Moreover, combination treatment of both ionizing radiation and resveratrol significantly decreased all studied cancer stem cells markers genes when compared to ionizing radiation alone suggesting that resveratrol exerts its anticancer effect through targeting cancer stem cells.

Multiple researches have revealed that the PC-3 cell line has elevated stem cell markers expression and is more aggressive relative to other cell lines such as CWR-22 and LNCaP (Haywood-Reid et al., 1997; Bonaccorsi et al., 2000; Singh et al., 2012). PC3 cells do not express androgen receptor and prostate-specific antigen and their proliferation is independent of androgen. (Tai et al., 2011)

CSCs are little subgroups of cancer cells that are accountable for tumor heterogeneity, showing high metastatic potential and resistance to traditional anticancer treatment (Nazio et al., 2019). Multiple researches have showed that CSCs were more resistant to ionizing radiation and chemotherapy and so they can survive initial therapy. This capability to survive suggests that cancer stem cells could drive post-treatment recurrence and cancer progression, and targeting these CSCs would increase the efficiency of cancer treatment, leading to an increasing number of patients being cured (Harris and Kerr, 2017; Du et al, 2019 ; Afify and Seno, 2019). The full eradication of malignancy can only be accomplished by targeting the small cell population that drives the origin of cancer, according to the CSC hypothesis (De Francesco et al., 2018) Several biomarkers such as CD44, CD49b, CD29, SOX2, OCT4 and CXCR4 have been used to classify CSCs in prostate cancer (Kobayashi and Noronha, 2015). Phytochemicals have been extensively studied in order to target CSCs effectively because they have no negative effects. Resveratrol is one such molecule that has recently attracted a lot of attention for its potential to target CSCs either alone or in combination (Bhaskara et al., 2020). However, its molecular pathways underlying tumor arrest are unknown. In the current study, RV increased susceptibility to induce cancer cell apoptosis by affecting gene expressions of multiple cancer stem cell markers.

In line with our findings, Qin (2020) showed that by inhibiting NAF-11, resveratrol greatly inhibits the characteristics of stem cells and the migration of pancreatic cancer cell. Peng and Jiang (2018) demonstrated that RV abolished osteosarcoma cell self-renewal ability, and decreased osteosarcoma stem cell subgroups proportion. $\mathrm{Fu}$ (2014) demonstrated that RV greatly prevents breast CSCs in both vitro and in vivo, effectively reducing the population of breast CSCs. 
Doublecortin like kinase 1 (DCLK1) is upregulated in a wide range of cancers, including pancreatic ductal adenocarcinoma and considered a cancer stem cell marker (Ferguson et al., 2020). Jiang et al., (2018) found that increased DCLK1 expression is associated with prostate cancer aggressiveness and predict poor survival in patients with prostate cancer. Our results showed that PC 3 cells express higher levels of DCLK1 and RV significantly repressed its expression. To the best of our knowledge, this is the first study detects and targets DCLK1gene by $\mathrm{RV}$ in PC3 cells.

With regards to EMT markers, our results showed that RV significantly increases E-Cadherin and decreases VIM genes expression in PC3 cells. RV can inhibit EMT and improve the antiproliferative effects of ionizing radiation. Our results are consistent with previous reports demonstrated that RV suppresses EMT and EMT-generated stem cell-like properties (Song et al., 2019; Guo et al., 2021). During EMT, epithelial cells lose their properties and acquire mesenchymal features. It has been suggested that transformed epithelial cells can be converted from a sessile, epithelial phenotype to a motile, mesenchymal phenotype by activating embryonic programs of epithelial plasticity. As a result, induction of EMT can result in invasion of the surrounding stroma, intravasation, dissemination, and colonization of distant sites. The dissemination of a CSC from the primary tumor followed by its re-establishment in a secondary site is required for sustained metastatic growth (Ye et al., 2015).

Regarding clonogenic assay, surviving fraction was significantly decreased in a dose dependent manner following treatment of PC-3 cells with IR at all doses. Interestingly, combining resveratrol treatment at $35 \mu \mathrm{M}$ with IR leads to significant depression in surviving fraction which was noticed with increasing the radiation dose. This result throws the light on $\mathrm{RV}$ as a potential radiosensitizer of PC3 cells. Our findings are in line with previous researchers indicating that, inhibited clonogenic survival of PC-3 cell line following combined treatment of RV with ionizing radiation (Fang et al., 2013; Heiduschka et al., 2014; Kortmann and Glasow, 2014; Da Costa Araldi et al., 2018). Prostate cancer radiosensitization by resveratrol may reduce the effective radiation dose and side effects associated with irradiation.

In conclusion, resveratrol alone or in combination with ionizing radiation exerts anticancer effect on $\mathrm{PC} 3$ cells. Therefore, resveratrol showed to be a good candidate for further studies as anticancer drug in the treatment of human prostate cancer. Resveratrol has a radiosensitizing ability triggered by reducing the expression levels of cancer stem cell markers and targeting EMT markers.

\section{Recommendations}

Further investigation and in particular experimental evaluations are required to explore clinical applications of resveratrol alone or in combination with available anticancer drugs in prostate and other cancers. For future studies, more pre-clinical and clinical evaluations of the effectiveness and safety of resveratrol and its active compounds are imperative.

\section{Author Contribution Statement}

Sanaa A. El-Benhawy research proposal idea, doing practical part of the study and the major contributor in writing the manuscript. Mohamed I. Morsi interpreting the study results and participation in manuscript writing. Enayat I. Fahmy interpreting the study results Moustafa A. Soula participation in the practical work and results interpretation and manuscript writing. Fatma Al Zahraa FH Khalil participation in the practical work. Amal R.R. Arab participation in the practical work, manuscript writing and results interpretation. All authors read and approved the final manuscript"

\section{List of abbreviations}

IR, Ionizing Radiation; Gy, Gray; RT, Radiotherapy; PC, prostate cancer; CSCs, cancer stem cells; GAPDH, Glyceraldehyde-3-phosphate dehydrogenase ; RV, resveratrol; EMT, epithelial to mesenchymal transition.

\section{Acknowledgements}

All authors have contributed significantly to this work.

\section{Recommendations}

Further investigation and in particular experimental evaluations are required to explore clinical applications of resveratrol alone or in combination with available anticancer drugs in prostate and other cancers. For future studies, more pre-clinical and clinical evaluations of the effectiveness and safety of resveratrol and its active compounds are imperative.

\section{Ethical and scientific approval}

This study was approved by ethical and scientific committees of Medical Research Institute, Alexandria University, Alexandria, Egypt.

\section{Availability of data and material}

The datasets are not publicly available but are available from the corresponding author on reasonable request.

\section{Conflict of interest}

No conflict of interest is declared.

\section{References}

Afify SM, Seno M (2019). Conversion of stem cells to cancer stem cells: Undercurrent of Cancer Initiation. Cancers, 11, 345.

Amor S, Châlons P, Aires V, Delmas D (2018). Polyphenol extracts from red wine and grapevine: Potential Effects on Cancers. Diseases, 6,106.

Bhaskara VK, Mittal B, Mysorekar VV, et al (2020). Resveratrol, cancer and cancer stem cells: A review on past to future. Curr Res Food Sci, 3, 284-95.

Bonaccorsi L, Carloni V, Muratori M, et al (2000). Androgen receptor expression in prostate carcinoma cells suppresses alpha6beta4 integrin-mediated invasive phenotype. Endocrinology, 141, 3172-82.

Chang L, Graham P, Jingli H, et al (2015). Cancer stem cells and signaling pathways in radioresistance. Oncotarget, 7, 
11002-17.

Chen YA, Lien HM, Kao MC, et al (2017). Sensitization of radioresistant prostate cancer cells by resveratrol isolated from Arachis hypogaea Stems. PLoS One, 12, e0169204.

Chen YA, Shoh HW, Lin YC, et al (2018). Simvastatin sensitizes Radioresistant prostate cancer cells by compromising DNA double -strand break repair. Front Pharmacol, 9, doi: 10.3389/f phar.2018.00600.

Da Costa Araldi IC, Bordin FPR, Cadoná FC, et al (2018). The in vitro radiosensitizer potential of resveratrol on MCF-7 breast cancer cells. Chem Biol Interact, 282, 85-92.

De Francesco EM, Sotgia F, Lisanti M P (2018). Cancer stem cells (CSCs): metabolic strategies for their identification and eradication. Biochem J, 475, 1611-34.

Diaz R, Nguewa PA, Diaz-gonzalez JA, et al (2009). The novel Akt inhibitor palomid529 (p529) enhances the effect of radiotherapy in prostate cancer. Br J Cancer, 100, 932-40.

Du FY, Ju GL, Xiao L, Zhou YM, Wu X (2019). Targeting cancer stem cells in drug discovery: Current state and Future perspectives. World J Stem Cells, 11, 398-420.

Fang Y, Bradley MJ, Cook KM, Herrick E J, Nicholl M B (2013). A potential role for resveratrol as a radiation sensitizer for mela $\neg$ noma treatment. $J$ Surg Res, 183, 645-53.

Ferguson FM, Nabet B, Raghavan S, et al (2020). Discovery of a selective inhibitor of doublecortin like kinase 1. Nat Chem Biol, 16, 635-43.

Fu Y, Chang H, Peng X, et al (2014). Resveratrol inhibits breast cancer stem -like cells and induces autophagy via suppressing wnt $/ \beta$ catenin signaling pathway. PLoS One, 9, e102535.DOI:101371/jounal pone.0102535.

Fulawka L, Donizy P, HalonmA (2014). Cancer stem cells - the current status of an old concept: literature review and clinical approaches. Biol Res, 47, 66.

Gong L, Zhang Y, Liu C, Zhang M, Han S (2021). Application of Radiosensitizers in Cancer Radiotherapy. Int J Nanomedicine, 16, 1083-102.

Guo K, Feng Y, Zheng X, et al (2021). Resveratrol and its analogs: Potent Agents to Reverse Epithelial-to-Mesenchymal Transition in Tumors. Front Oncol, 11, 644134.

Harris KS, Kerr BA (2017). Prostate cancer stem cell markers drive progression, therapeutic resistance, and bone metastasis. Stem Cells Int, 2017, 8629234.

Haywood-Reid,P L, Zipf DR ,Springer WR (1997). Quantification of integrin subunits on human prostatic cell lines - comparison of nontumorigenic and tumorigenic lines. The Prostate, 31, 1-8.

Heiduschka G, Lill C, Seemann R, et al (2014). The effect of resveratrol in combination with irradiation and chemotherapy. Strahlenther Onkol, 190, 75-80.

Huang H, Chen X, Li D, et al (2015). Combination of $\alpha$-Tomatine and curcumin inhibits growth and induces apoptosis in human prostate cancer cells. PLoS One, 10, e0144293.

Jasiński M, Jasińska L, Ogrodowczyk M (2013). Reseratrol in prostate diseases- a short review. Cent European J Urol, 66, 144-9.

Jiang D, Xiao C, Xian T, et al (2018). Association of doublecortin-like kinase 1 with tumor aggressiveness and poor biochemical recurrence-free survival in prostate cancer. Onco Targets Ther, 11, 1077-86.

Kamalidehghan B, Ghafouri-Fard S, Motevaseli E, Ahmadipour F (2018). Inhibition of human prostate cancer cells and targeting of PC-3 derived prostate cancer stem cells with koenimbine, a natural dietary compound from Murraya koenigii (L) Spreng. Drug Res Devel Ther, 12, 1119-33.

Kobayashi NC, Noronha SM (2015). Cancer stem cells: a new approach to tumor development. Rev Assoc Med Bras, 61, 86-93.
Kortmann P R, Glasow A (2014). Resveratrol enhances radiation effects on clonogenic survival in human medulloblastoma cell lines. Neurooncol, 16, 35.

Koushki M, Amiri-Dashatan N, Ahmadi N, Abbaszadeh HA, Rezaei-Tavirani M (2018). Resveratrol: A miraculous natural compound for diseases treatment. Food Sci Nutr, 6, 2473-90.

Mortezaee K, Najafi M, Farhood B, et al (2020). Resveratrol as an adjuvant for normal tissues protection and tumor sensitization. Curr Cancer Drug Targets, 20, 130-45.

Murata K, Saga R, Monzen S, et al (2019). Understanding the mechanism underlying the acquisition of radioresistance in human prostate cancer cells. Oncol Lett, 17, 5830-8.

Naponelli V, Modernelli A, Bettuzzi S, Rizzi F (2014). Roles of autophagyinduced by natural compounds in prostate cancer. Bio Med Res Int, 2015, doi.org/10.1155/2015/121826.

Nazio F, Bordi M, Cianfanelli V, Locatelli F, Cecconi F (2019). Autophagy and cancer stem cells: molecular mechanisms and therapeutic applications. Cell Death Differ, 26, 690-702.

Peng L, Jiang D (2018). Resveratrol eliminates cancer stem cells of osteosarcoma by STAT3 pathway inhibition. PLoS One, 13, e0205918.

Qin T, Cheng L, Xiao Y, et al (2020). NAF-1 inhibition by resveratrol supresses canver stem cell-like properties and the invasion of pancreatic cancer. Front Oncol, 10, doi:10.3389 fonc.2020.01038.

Rawla P (2019). Epidemiology of prostate cancer. World $J$ Oncol, 10, 63-89.

Selvaraj S, Sun Y, Sukumaran P, Singh BB (2016). Resveratrol activates autophagic cell death in prostate cancer cells via downregulation of STIM 1 and mToR pathway. Mol Carcinog, 55, 818-31.

Shipley WU, Seiferheld W, Lukka HR, et al (2017). NRG Oncology RTOG. Radiation with or without Antiandrogen Therapy in Recurrent Prostate Cancer. N Engl J Med, 376, 417-28.

Silk N, Reich J, Sinha R, et al (2021). The effects of resveratrol on prostate cancer through targeting the tumor microenvironment. J Xenobiot, 11, 16-32.

Singh S, Chitkara D, Mehrazin R, et al (2012). Chemoresistance in prostate cancer cells is regulated by miRNAs and hedgehog pathway. PLoS One, 7, e40021.

Song Y, Chen Y, Li Y, et al (2019). Resveratrol suppresses epithelial-mesenchymal transition in GBM by regulating smad-dependent signaling. Biomed Res Int, 2019, doi: 10.1155/2019/1321973.

Sun Y, Zhou QM, Lu YY, et al (2019). Resveratrol inhibits the migration and metastasis of MDA-MB-231 human breast cancer by reversing TGF- $\beta 1$-induced epithelial mesenchymal transition. Molecules, 24, 1131.

Tai S, Sun Y, Squires JM, et al (2011). PC3 is a cell line characteristic of prostatic small cell carcinoma. Prostate, 71, 1668-79.

Wang BD, Ceniccola K, Hwang S, et al (2017). Alternative splicing promotes tunour aggressiveness and drug resistance in African American prostate cancer. Nat Commun, 8, doi 10.1038/ncomms 15921.

Ye X, Weinberg RA (2015). Epithelial-mesenchymal plasticity: A Central Regulator of Cancer Progression. Trends Cell Biol, 25, 675-86.

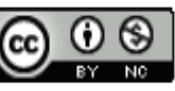

This work is licensed under a Creative Commons AttributionNon Commercial 4.0 International License. 